\title{
Influence of Dosing Time of Enalapril on the Daily Variation of Pulmonary Function : A Preliminary Study
}

\author{
Koh-ichi SUGIMOTO* Masami OHMORI* \\ Shuichi TSURUOKA* Kazuhiro HARADA* \\ Kei MATSUSHITA* Atsuhiro KAWAGUCHI* \\ Hideto $\mathrm{TOH}^{*}$ and Akio FUJIMURA*
}

(Received on July 17, 2000)

* Department of Clinical Pharmacology, Jichi Medical School
3311-1 Yakushiji, Minamikawachi-machi, Kawachi-gun, Tochigi 329-0498, Japan

This study was performed to determine the influence of dosing time of enalapril, an angiotensin-converting enzyme inhibitor, on pulmonary function. Enalapril $(10 \mathrm{mg}$ ) or placebo was given orally at $10: 00$ and $22: 00$ to eight healthy, nonsmoking, male adults in a randomized, double-blind crossover design. Peak expiratory flow (PEF) was determined at $16: 00$ on day 1 and $04: 00$ and $16: 00$ on day 2 . PEF at $04: 00$ was significantly lower than that at $16: 00(\mathrm{p}<0.01)$. Enalapril dosed at $10: 00$ or $22: 00$ did not significantly influence the daily variations of $\mathrm{PEF}$ compared to placebo. The daily variation of pulmonary function might not be influenced by a single dosing of enalapril in the morning or evening.

Key words : enalapril, peak expiratory flow, chronopharmacology

\section{Introduction}

Pharmacokinetic and pharmacodynamic profiles of angiotensin-converting enzyme (ACE) inhibitors are varied with their dosing time. For example, the response of bradykinin (BK), which is involved in dry cough ${ }^{1)}$, is greater following enalapril, an ACE inhibitor, given in

* 自治医科大学臨床薬理学 干 329-0498 栃木県河内郡南河内町薬師寺 $3311-1$ the morning than in the evening ${ }^{2}$. We recently observed the amelioration of enalapril-induced dry cough by switching the dosing time from morning to evening ${ }^{3)}$. Deterioration of bronchial spasm is another adverse effect of ACE inhibitors in some hypertensive patients with asthma ${ }^{4,5)}$. However, a chronotherapeutic approach for reducing this harmful effect has not been performed.

This study was the first step to evaluate the influence of dosing time of enalapril in the daily 


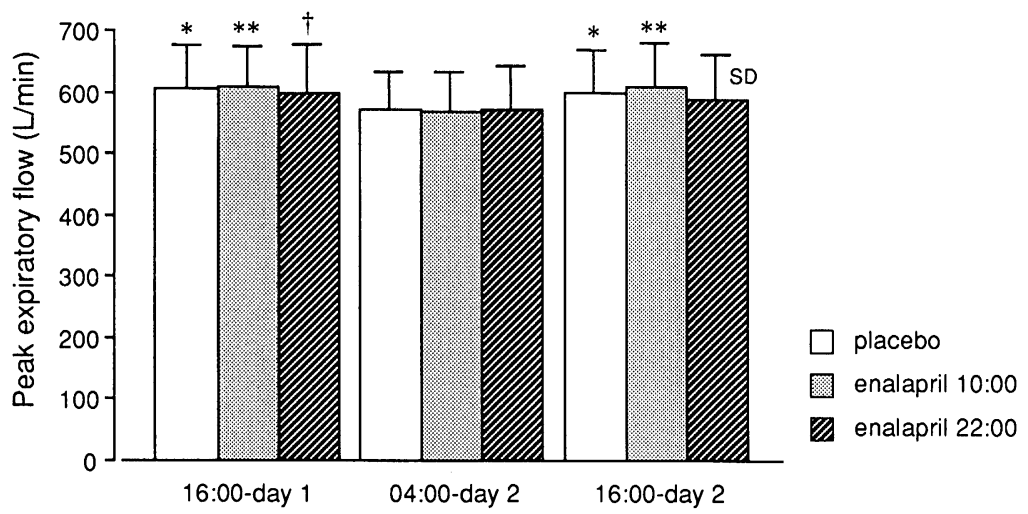

Fig. 1 Effects of a single oral administration of enalapril $(10 \mathrm{mg})$ at $10: 00$ and $22: 00$ on the daily variation of peak expiratory flow in normal subjects $(n=8)$

${ }^{*}: \mathrm{p}<0.05,{ }^{* *}: \mathrm{p}<0.01$ and $^{\dagger}: \mathrm{p}<0.001$ vs. $04: 00$-day 2 by paired t-test.

variation of pulmonary function. As it is possible that enalapril enhances bronchial obstruction and worsens the symptom in asthmatics, healthy subjects participated in this study.

\section{Subjects and Methods}

Eight healthy male subjects (nonsmokers, mean age 35 years) participated in the study. All subjects were in good health without any history of pulmonary disease. During the screening period, forced expiratory volume in one second $\left(\mathrm{FEV}_{1}\right)$ was more than $75 \%$ of the predicted value in each subject. The study protocol was approved by the Institutional Ethical Committee. All participants gave informed written consent.

The study was performed in a randomized, double-blind crossover design with at least a 7-day washout phase. Subjects orally took 10 mg of enalapril maleate (Renivace ${ }^{\circledR}$ ) or placebo at morning $(10: 00)$ and evening (22:00) on day 1 . To ensure a double-blind technique, powdered enalapril or lactose (as placebo) was wrapped with a wafer. Peak expiratory flow (PEF) was measured by a peak flowmeter (Peakman $8^{\circledR}$ Chest M. I. Co. Ltd., Tokyo,
Japan) at $16: 00$ on day 1 , and at $04: 00$ and $16: 00$ on the following day (day 2). Subjects refrained from drinking alcohol and caffeinecontaining beverages during the study. PEF measurement was performed six times at each point and the best three readings were averaged.

\section{Results}

On placebo treatment, PEF showed a significant daily variation in normal subjects (Fig. 1). $\mathrm{PEF}$ at $04: 00(573 \pm 61[\mathrm{SD}] \mathrm{L} / \mathrm{min})$ was significantly lower than at $16: 00(605 \pm 70 \mathrm{~L} / \mathrm{min}$ on day $1,598 \pm 69 \mathrm{~L} / \mathrm{min}$ on day $2 ; \mathrm{p}<0.01$ by ANOVA). The daily variation of $\mathrm{PEF}$ was also evident when enalapril was administered at $10: 00(\mathrm{p}<0.001)$ or $22: 00(\mathrm{p}<0.005$ by ANOVA). However, this daily variation of $\mathrm{PEF}$ in the morning or evening trial was not significantly different with the placebo trial. Especially, the drug did not reduce this variable further at $04: 00$ compared to the placebo trial.

\section{Discussion}

Pulmonary function shows a daily variation with a trough around $04: 00$ in patients with 
bronchial asthma as well as in normal subjects ${ }^{6}$, which is similar to the present findings. This may explain the increased frequency of asthma attacks in the early morning ${ }^{7}$. The mechanism of the daily variation in pulmonary function has not been fully evaluated, but enhanced parasympathetic activity during this critical period in patients with asthma is postulated as a factor ${ }^{8}$. ACE inhibitors are known to elevate vagal tone ${ }^{9)}$. In addition, we observed that a single, therapeutic dose of ramipril, an ACE inhibitor, increases heart rate variability in normal subjects, indicating the activation of parasympathetic nerves ${ }^{10)}$. Therefore, we think that the activity of the nervous system might also be enhanced by a single dosing of $10 \mathrm{mg}$ enalapril. In this study, we could not detect any influence on PEF following enalapril at 10:00 or 22:00 in normal subjects. These results suggest that the role of the parasympathetic nerves in the daily variation of pulmonary function is relatively small in normal subjects. However, as vagal tone is elevated in patients with asthma compared to normal subjects, and contributes to nocturnal asthma ${ }^{8,11)}$, the possibility that enalapril stimulates the parasympathetic activity further in asthmatic patients and decreases pulmonary function, especially in the early morning can not be ruled out.

$\mathrm{ACE}$ inhibitors are reported to increase $\mathrm{BK}$ level in the bronchus ${ }^{1)}$, which leads to airway narrowing ${ }^{12)}$. In the present study, enalapril did not influence the pulmonary function in normal subjects. However, as BK causes an augmented bronchoconstriction in asthmatic patients ${ }^{13)}$, enalapril might reduce PEF in these patients. We previously demonstrated that the response of $\mathrm{BK}$ to enalapril is greater in morning than in evening trials in hypertensive subjects ${ }^{3}$. In addition, we showed that the BK-related response (writhing reaction) is greater after captopril, an ACE inhibitor, at an active period than at a resting period in mice ${ }^{14)}$. Therefore, we think that the BK-induced bronchoconstriction might also be varied with its dosing time.

In the present study, a single dose of enalapril at $10: 00$ or $22: 00$ did not reduce $\mathrm{PEF}$ in the early morning further. To avoid potential adverse effects, this study was performed in normal subjects. The present findings can not be extrapolated to hypertensive patients with asthma. Chronic treatment might be needed to clarify whether the influence of enalapril on pulmonary function depends on the dosing time.

\section{Acknowledgment}

We wish to thank Chie Fukushima for technical assistance.

\section{References}

1) Semple, P.F.: Putative mechanisms of cough after treatment with angiotensin converting enzyme inhibitors. J. Hypertens., 13 (Suppl. 3) : S 17-S 21 (1995).

2) Sunaga, K., Fujimura, A., Shiga, T., et al. : Chronopharmacology of enalapril in hypertensive patients. Eur. J. Clin. Pharmacol., 48 : 441445 (1995).

3) Fujimura, A., Ebihara, A., Shiigai, T., et al. : Amelioration of enalapril-induced dry cough by changing dosing time from morning to evening ; a preliminary trial. Jpn. J. Clin. Pharmacol. Ther., 30 : 741-744 (1999).

4) Semple, P.F. and Herd, G. W. : Cough and wheeze caused by inhibitors of angiotensin converting enzyme. N. Engl. J. Med., 314 : 61 (1986).

5) Lipworth, B. J., McMurray, J. J., Clark, R. A., et al. : Development of persistent late onset asthma following treatment with captopril. Eur. Respir. J., $2: 586-588$ (1989).

6) Hetzel, M. R. and Clark, T. J. H. : Comparison of normal and asthmatic circadian rhythms in peak expiratory flow rate. Thorax, $35: 732-738$ (1980).

7) Syabbalo, N. : Chronobiology and chronopharmacology of nocturnal asthma. Int. J. Clin. Pract., 51: 455-462 (1997).

8) Morrison, J. F. and Pearson, S. B. : The parasym- 
pathetic nervous system and diurnal variation of lung mechanics in asthma. Respir. Med., 85 : 285289 (1991).

9) Binkley, P. F., Haas, G. J., Starling, R. C., et al. : Sustained augmentation of parasympathetic tone with angiotensin-converting enzyme inhibition in patients with congestive heart failure. J. Am. Coll. Cardiol., $21: 655-661$ (1993).

10) Sugimoto, K., Kumagai, Y., Tateishi, T., et al. : Effects on autonomic function of a new angiotensin converting enzyme inhibitor, ramipril. J. Cardiovasc. Pharmacol., 13 (Suppl. 3): S 40S 45 (1989).

11) Kallenbach, J. M., Webster, T., Dowdeswell, R., et al. : Reflex heart rate control in asthma. Chest, $87: 644-648$ (1985).

12) Ichinose, M., Belvisi, M. and Wayne, M. : Bradykinin-induced bronchoconstriction in guinea pig in vivo : role of neural mechanisms. J. Pharmacol. Exp. Ther., 253 : 594-599 (1990).

13) Fuller, R. W., Dixon, C. M. S., Cuss, F. M., et al. : Bradykinin-induced bronchoconstriction in humans : mode of action. Am. Rev. Respir. Dis., 135: 176-180 (1987).

14) Sakamoto, K., Sugimoto, K. and Fujimura, A. : Effect of captopril on the time-dependent variation of kaolin-induced writhing reaction. Chronobiol. Int., $15:$ 173-179 (1998). 